\title{
Institutional Autonomy: Implications for Teaching and Research in Public Universities in Uganda
}

\author{
Irene Etomaru ${ }^{1}$, Margaret Stella Ujeyo ${ }^{1}$, Aloyce Luhamya ${ }^{1} \&$ Joseph Kimoga $^{1}$ \\ ${ }^{1}$ College of Education and External Studies, Makerere University, Uganda \\ Correspondence: Irene Etomaru, College of Education and External Studies, Makerere University, Uganda.
}

Received: March 30, 2016

Accepted: May 6, 2016

Online Published: July 20, 2016

doi:10.5430/irhe.v1n2p133

URL: http://dx.doi.org/10.5430/irhe.v1n2p133

\begin{abstract}
This paper focused on examining the implications of institutional autonomy for teaching and research in public universities in Uganda. What constitutes university autonomy and what are its likely effects on establishing a balance between teaching and research in public universities in Uganda is the pertinent question raised in this paper. The paper argues that the university as an autonomous institution at the heart of societies produces, examines, appraises and hands down culture by research and teaching. Thus, research and teaching must be morally and intellectually independent of all political and economic interference. Literature reviewed through a constructivist epistemological lens revealed that much as official government documents pronounced institutional autonomy for public universities in Uganda, teaching and research seem to be influenced by external forces to a greater extent. Based on resource dependence theory, we conclude that pseudo autonomy constrains faculty independence in both teaching and research. We recommend that public universities in Uganda ought to revisit the professional work of the academics in the wake of increasing demands in order to balance between research and teaching.
\end{abstract}

Keywords: institutional autonomy, public universities, teaching, research

\section{Introduction}

Public universities occupy a unique place in society. Much as they receive public funding, they are not part of government and yet not so much private as non-profit bodies despite being large in corporate terms. They enjoy a special status because of their tradition, history and values they represent in society (Fumasoli, Gornitzka \& Maassen, 2014). Their independent role as teaching and research institutions is reflected by provisions in enabling legislations with reference to free and critical enquiry, the dissemination of knowledge, promoting public debate, academic independence and operating with integrity $(\mathrm{Go} 8,2008)$.

Universities in their creative, freethinking mode are a vital resource. Such freedom however poses a dilemma for both government and universities as the special status has to be linked to accountability (Pullin, 2004). Public universities are largely funded from the public purse, in an era where there seems to be a deepening crisis of trust and a culture of suspicion about public bodies and professionals, freedom is accompanied by calls for greater accountability (Bolton \& Lucas, 2008; Asiimwe \& Steyn, 2013). Detailed regulations, memoranda, instructions, guidance, and lists of best practice flood into universities mainly focusing on processes rather than outcomes (Go8, 2008). The challenge to universities, government and society is to articulate a compact that recognizes the value of autonomy and freedom and supports them. Finding an appropriate balance between credible accountability and effective autonomy is imperative (Akalu, 2014). Public universities need freedom from oppressive mechanisms that undermine their potential in performing the core functions of teaching, research and community engagement.

Universities world over are concerned about how to rationally respond to the political demands of government and demands of other external forces and at the same time uphold the principles of institutional autonomy and academic freedom in their internal operations (Pullin, 2004). Cognizant of this, declarations have been made on institutional autonomy and academic freedom, for example, the Magna Charta of European Universities-Bologna-1988, Lima declaration-1988, Kampala declaration-1988 and the Dar-es-Salam declaration-1990 (CEPES, 1992). These declarations affirm the need for autonomy and academic freedom for universities. This paper therefore examined how the principles of institutional autonomy and academic freedom can be upheld in establishing the balance between teaching and research. 
The paper is structured in three sections. In the first section, the concepts of institutional autonomy and academic freedom are explained, the next section is an explanatory review of literature on the implications of institutional autonomy and academic freedom for teaching and research in public universities with specific reference to how best to establish a balance between teaching and research. We then present the theory underpinning our study. The last section of the paper presents the method of inquiry, findings, discussions, conclusion and recommendations on avenues of exploiting the potentials of institutional autonomy and academic freedom in teaching and research without oppressive accountability.

\section{Conceptualization of Institutional Autonomy and Academic Freedom}

Scholars have given various explanations to the concepts of institutional autonomy and academic freedom and in some instances used the two terms interchangeably. Drawing from the definitions given by scholars like Okai \& Worlu (2014), Martin (2014), Nokkala \& Bacevic (2014) and CEPES (1992), we argue that the two terms do not mean the same. The notion of autonomy can be understood at the two levels of institutional and individual autonomy (Yang, Vidovich \& Currie, 2007). Institutional autonomy is the right to develop strategy, fully exercise and practice academic freedom and self-government with regard to internal activities (CEPES, 1992; Fielden 2008). This implies freedom from interference by either the state or any other external force in terms of the internal organization of the university, its governance, the funding arrangement, the generation of income for its sustainability, recruitment of its staff, admission of students and the freedom to conduct teaching, research and publications (Nokkala \& Bacevic, 2014). Academic freedom on the other hand is the freedom of individual faculty to follow a particular path of intellectual conception and within a particular institution (CEPES, 1992). That is, freedom to choose what to put forward in teaching, research and publications. Therefore, whereas academic freedom is particular to an individual academic, institutional autonomy is for the entire university (Armbruster, 2008). Although the two levels greatly overlap, a high degree of institutional autonomy may not necessarily promote individual autonomy because sometimes institutional autonomy is used to suffocate academic freedom (Yang, Vidovich \& Currie, 2007).

Institutional autonomy and academic freedom are essential prerequisites for universities to fulfill the core functions of teaching, research and community engagement (Asiimwe \& Steyn, 2013). Open and independent inquiry, unfettered teaching and dissemination of knowledge, the defining characteristics of a university rest on autonomy and academic freedom. Research has shown that violation of academic freedom and institutional autonomy has high costs in terms of intellectual regression (Appiagyei-Atua, Beiter \& Karran, 2015). Universities must remain free to set their own research agenda and give the staff the freedom to conduct research as well as debate and publish their findings as they see fit in order to compete effectively at home and abroad and contribute to socio-economic development (Kasozi, 2003, Brown, \& Krager, 2013). Without such autonomy, universities cannot contribute fully to achieve the governments' objectives of attaining competitive advantage in the global knowledge economy (Purcell, 2008).

\section{Literature Review}

\subsection{Institutional Autonomy, Teaching and Research}

University autonomy has a direct link to sources of funding. Institutions that derive more of their income from non-government sources enjoy more autonomy than those that rely heavily on government funding (Chiang, 2004). According to Yang, Vidovich and Currie (2007) diversification of sources of funding grants the university more autonomy, they however caution that the autonomy comes with other related challenges. Leisyte and Dee (2012) submit that public universities cannot boast of total autonomy because they are funded by government which definitely influences their business. They add that the research agenda of most universities are influenced by external funding agencies. Rostan (2013) adds credence to the argument by asserting that governments and funding agencies put pressure on academics to engage more in research than teaching thus affecting the balance between the two.

In addition to funding, governments also influence universities through policy formulation. In developing countries, for example, national governments continue to steer higher education policy, particularly in public universities in direction that is generally considered as the national interest (Sirat, 2010). Universities are avenues for achieving and implementing government priorities and policies (Olsen, 2007). The environment in which universities and faculty members pursue their mission is therefore affected by government policies (Rostan, 2013). Policy initiatives by governments have therefore greatly affected the environment within which teaching and research take place. According to Olsen (2007), national priorities determine the growth of the university. The functions of teaching and research are therefore used as tools for promoting economic growth and development. 
There has been increasing accountability demand from the university by external factors including government over the past years which has threatened its autonomy in making decisions on the different forms of knowledge (Osservatorio Universitum, 2005; Capano, 2008). Accountability is an engine for external forces to influence activities of the university and therefore affects the balance between teaching and research. According to Sirat (2010) as important producers in the knowledge based economy, universities are continuously being scrutinized by both the state and society in terms of their relevance and accountability. Nokkala \& Bacevic (2014) argue that universities will not become innovative and responsive to change unless they are given real autonomy. They further posit that the discourse on institutional autonomy has moved from autonomy as given by the state to autonomy as won by universities. Leadership in public universities needs to device sound funding mechanisms to win autonomy in teaching and research.

The reduction in public expenditure in higher education has made public universities to find other avenues of increasing revenue. This has increased the number of stakeholders who also intervene in the business of the university (Akalu, 2014). External funders, for example do influence research policies of universities by dictating the themes of research that their money should fund. Lebeau \& Papatsiba (2016) assert that funded collaborations in research schemes and their expectations regarding the impact of collaboration on research orientation and productivity will further undermine the autonomy of the academic in profession in its regulation of research practice and out puts. External agencies mainly fund research activity and less of teaching thus institutions may find it hard to devote equal resources for both. Accountability demands by government and other funding agencies bring into force greater managerial oversight with strict performance management mechanisms (Gehrke \& Kezar, 2015; Santiago, Carvalho, Amaral \& Meek, 2006). In this context academics are required to engage more in research.

Higher education has a central role in the knowledge economy and the fulfillment of this role requires that universities enter into relationships with partners and other stakeholders in the knowledge society (Chatha, 2008). This has led to breaking down of boundaries that have been critical for justification of academic rights to self-government and freedom of inquiry (Henkel, 2007). The ideal of the university as a sovereign, bounded territory, free by right from intervention in its governance of knowledge development and transmission has been superseded by ideals of engagement with society in which academic institutions are axial structure (Sirat, 2010). Such partnerships are short term and make it impossible for the institutions to pursue long term research because emphasis is on current needs or interests. Teaching curricula are being organized to suit market needs with more value for practical training. In many cases choices for topics in post graduate research depend on the funding agency or industrial partners within whose companies the students carry out the research (Gul, Gul, Kaya \& Alican, 2010).

The environment of public universities in Africa has changed tremendously since the Dar es Salaam Declaration (1990) on Academic Freedom and Social Responsibility of Academics and the Kampala Declaration (1988) on Intellectual Freedom and Social Responsibility (Ibrahim, 2010). Dill (2001) argues that the changing context of higher education is altering the traditional means by which governments regulate universities. However, the threat to academic freedom and university autonomy is still largely external, emanating from political systems which interfere with the governance of institutions and constrict the space of intellectuals to organically under take their social mandate. Santiago et al. (2006) explain how the changing environment of higher education has placed conflicting demands on academics. The change in the environment has greatly altered the context in which academics work and places more pressure on them to engage in research.

Successful universities require a supportive governance structure in which universities have autonomy to achieve objectives whether in research or teaching. There is no country in the world that can move significantly forward without guaranteeing autonomy and academic freedom to its tertiary institutions (Okai \& Worlu, 2014; Owhondah, 2008). Chiang (2004) asserts that the degree of university autonomy depends not only upon how much room for self-government is left to a university, but also upon how much ability a university has to fulfill its mission. An autonomous university in principle, should enact its own constitution, define its mission and control its budget and employment (Armbruster, 2008). What is considered to be the appropriate level of autonomy is an important issue in policy debates on university governance, organization and funding (Fumasoli, Gornitzka \& Maassen, 2014). Individual academic autonomy and freedom in teaching and research has been neglected with more focus now on institutional autonomy. As Schmidt \& Langberg (2007) posit, without institutional autonomy and academic freedom, universities cannot achieve their potential nor fully contribute to the knowledge based society. However, institutional autonomy should not be taken to mean absence of external control but rather as a matter of empowering institutions in a responsible way. This entails finding an appropriate balance between accountability and autonomy. 


\subsection{Theoretical Review}

Resource dependency theory postulated in the 1970s by Jeffrey Pfeffer and Gerald, R. Salancik (Pfeffer \& Salancik, 1978) provided a useful theoretical framework for this paper. The theory is based on the premise that the longevity of an organization depends upon its ability to gather essential resources from outside its boundaries. While universities require autonomy to pursue the missions of teaching and research, as institutions within society that depend on resources and continued support, they are accountable to many groups within the environment. Thus, resource dependence theory frames the context within which both the state and the universities operate.

The theory analyses organizations in the context of their external environment and provides a framework for discussing change. The propositions of the theory are that organizations exist within an environment not in isolation; the environments are unstable and subject to change; an organization's efficiency is less crucial to its survival than an organization's effectiveness in meeting stakeholders demands and that organizations are not concrete entities or collection of individuals but a fluid coalition of various interest groups and behaviors (Pfeffer \& Salancik, 1978). This suggests that resources are very central to the success of an organization because the access to and control of resources is a basis of organizational power. Access to resources enhances the organization's ability to compete with others and determines its independence. The criticality, magnitude and use of a resource determine its importance to a particular organization. Thus, universities relationship with the external environment is critical to attainment of the core functions of teaching, research and community engagement.

The theory asserts that since organizations do not usually control the resources that they require to carry out their work, they must adopt certain strategies so as to sustainably have access to resources. By networking with many partners, organizations try to reduce dependency on one source of resources. Resource dependency theory focuses on the assumption that an organization's survival depends on power to control resource allocation. Its central proposition is that organizations will use different tactics to manage their resource dependencies and achieve greater autonomy leading to reduction of uncertainty in the flow of resources from its environment.

The propositions of the resource dependency theory have direct implications for institutional autonomy and academic freedom in regard to teaching and research. For universities to make decisions regarding teaching and research without control and direction from external stakeholders such as politicians, donors, society, they need power to control resource allocation. However, in Uganda, public universities heavily rely on government subsidies, donor funding and funding from collaborative net-works with international agencies. This has serious implications for autonomy and academic freedom in regard to the core functions of teaching and research. We therefore adopted the resource dependence theory as the theoretical lens on which to base our arguments.

\section{Methods}

This paper is based on literature reviewed through a constructivist epistemological lens and analysis of pertinent official national and institutional documents. The major documents reviewed were: Universities and Other Tertiary Institutions' Act 2001; National Council for Higher Education Quality Assurance Framework for Universities and the Licensing Procedure for Higher Education Institutions (2008); Report of the Visitation Committee to Public Universities in Uganda (2007); Uganda National Science, Technology and Innovation Policy(2008). Makerere University Staff Promotions Policy (2014); Makerere University Human Resource Manual (2006); Kyambogo University Human Resource Manual(2014); Mbarara University of Science and Technology Human Resource Manual (2010); Busitema University Recruitment and Promotion Policy(2011); Makerere University ICT Policy Master Plan (2010-2014); Muni University 5 Year Strategic Plan 2010/2011-2014/2015; Kyambogo University Strategic Plan 2007/2008-2011/2012; Busitema University Strategic Plan 2014/2015-2018/2019; Makerere University Teaching and learning Policy (2013); Makerere University Student Evaluation of Teaching and Learning Policy (2009).

\section{Findings}

Public universities in Uganda are semi-autonomous (Republic of Uganda, 2001). They experience a certain level of government control but also enjoy some degree of autonomy. We submit that they exercise a great level of autonomy in deciding their teaching and research agenda. Institutional autonomy in teaching is reflected in the designing of courses and degree programs. The institution in its capacity has freedom to design and develop university courses appropriate to the knowledge economy and relevant to the needs of learners. Makerere University for instance has used its autonomy to design and run many new course units and degree programs (Makerere University Annual Report, 2013). 
The institutions have autonomy in choosing the methods of teaching that are appropriate to realize educational goals and to evaluate and assess their teaching, courses and programs without interference from government. The Makerere University Student Evaluation of Teaching and Learning Policy (2009) envisages that one of its purposes of evaluating teaching and learning is to assist staff to engage in scholarly review of their teaching by reflecting on course design, delivery, student engagement and assessment. The Makerere ICT policy and the teaching and learning policy clearly stipulate that the University will enhance its teaching and learning approaches by utilizing modern instructional materials and methods (Makerere University, 2010; Makerere University, 2012).

As mentioned in the literature, governments have moved away from direct control of universities but use regulatory bodies to influence activities in these institutions (Taiwo, 2012). The National Council for Higher Education (NCHE) and the Joint Admissions Board (JAB) are bodies through which government influences university activity. The NCHE approves and accredits all courses and sets minimum standards for the institutions (The Republic of Uganda, 2001). It also sets the minimum qualification for university entry and minimum grading system to be used by all universities in the country. The Council carries out a supervisory role on behalf of government (The Republic of Uganda, 2001). On the other hand JAB takes charge of admissions of government sponsored students at all public universities. Public institutions exercise a certain level of autonomy in admitting the private undergraduate students and all the post graduate students without due influence from government. However the programs must be in line with national goals and approved by NCHE (Government of Uganda, 2001).

Academics in Ugandan universities are free to express their views and carry out research in any field. However institutional autonomy may be used by management to suffocate the freedom of individual academics. Universities set up research themes according to interest of funding agencies thus restricting the freedom of researchers. Whoever undertakes research in a topic outside the theme may not receive funding unless they seek their own funding from other agencies. This is evident in Makerere University Human Resource Manual (2006); Kyambogo University Human Resource Manual (2014) and Mbarara University of Science and Technology Human Resource Manual (2010).

Public universities in Uganda are funded by government although they also generate additional income through the private students' schemes. As already mentioned in the literature, state funding allows government to influence the activities of the university (Chiang, 2004, Leisyte \& Dee, 2012; Rostan, 2013). The university draws its budget which must be approved by the Ministry of Finance and thereafter it is restricted to spend within the approved budget lines. The flexibility of the university in using resources for teaching and research has been greatly affected. Thus, Public universities in Uganda cannot respond quickly to short term demands from society because of influence from government. Nybom (2008) contends that a high level of institutional autonomy gives the university strength and capacity to respond quickly to demands. It is for this reason that private institutions in Uganda seem to move faster than the public ones when it comes to program and curricula adjustments according to demand.

It has been noted that policy initiatives by governments influence research and teaching at universities (Rostan, 2013). A number of policies in place seem to drive the workings of the public universities towards research, for example, the National Science, Technology and Innovation Policy (STI) (2008) emphasizes science and technology. The theme 'song' of government is on the promotion of science and technology. As a result most institutions place emphasis on research so that they can be seen as research institutions. Moreover the research funds that government sends to universities is mainly spent on research in the areas of science and technology.

Policy documents such as the Human Resource Policies, Appointment and Promotion Policies and Staff Awards and Recognition Policies of Makerere University, Kyambogo University and Busitema University among others indicate that universities recognize both functions of research and teaching to be important. The objectives of the staff awards policy include excellent performance in both teaching and research in addition to other parameters such as service and administrative leadership. To merit promotion, academics have to excel in teaching, research, supervision of students and scholarship among other considerations. However whether these policies establish a balance between the two functions is cause for debate.

Academics are expected to engage in research and teaching at the same time, yet the latter is rated lowly when it comes to promotion of staff. Promotional policies emphasize the number of publications required for one to get to another level. The Makerere University policy on promotions requires three publications for one to be promoted to the position of senior lecturer (Makerere University, 2014) and this is a similar trend in all public universities. Academics that do not engage in extensive research miss out on being promoted. Universities use their autonomy to lay more emphasis on research because even university ratings regionally or globally are based on research publications and not teaching. The balance is therefore tilting towards research because it seems to be regarded as 
more important than teaching. It is not uncommon to hear universities boasting that they are research universities and yet their functions involve both.

Public universities exercise their freedom to put in place guidelines that enhance teaching and research. A framework for teaching includes program duration and number of contact hours among other related factors. For instance each department of higher education has a team of experts or committee responsible for assessing which courses should be major and which ones should be minor (core and elective course) at all levels of the university. Additionally, these institutions have established research and graduate directorates which give them the power to admit postgraduate students and determine the research direction of the university without much influence from government. Research grants from government are used for pursuing research in themes determined by the universities themselves.

Universities enjoy more autonomy when they diversify their sources of funding. Makerere for example has entered partnership with the Swedish International Development Agency (SIDA) in order to increase funding for training and capacity building in research and not teaching. The recent call for study scholarships by the Makerere Directorate of Research and Graduate Studies (New Vision, November 9, 2015) attests to this fact. It would be correct to argue that as universities become more autonomous, they build partnerships that require that they engage more in research than teaching.

Although government emphasizes research, the country does not have a national research policy and the money released for research is too little (Daily Monitor, November 2015). While universities would like to do more research, they are limited in doing so because of shortage of funds. Busitema University for example is reported to be receiving only 70 million shillings from government for research every year. With limited funding universities and academics are left with no choice but to majorly engage in teaching. Apart from Makerere that has established itself as a research institution many of the newer public institutions are struggling with research since they have not yet established a reputation to be able to attract enough external funding. In most of these institutions, staff are basically teaching and carrying out little research work. The heavy reliance on government funding tends to stifle research efforts in the relatively younger public institutions.

\section{Discussions}

We argue that both research and teaching are important functions of the university and each of them must be given due consideration without suffocating the other. It is not only important that universities address and train for current needs, but equally important that they develop conceptual skills and habits that equip their graduates to adapt to change. The lack of balance between teaching and research is a consequence of limited resources to public universities. Abrutyn (2009) contends that resources provide the material for constructing a system of authority that affords some actors in a social system more freedom in their actions than others. Thus, inadequacy of resources suffocates the authority of public universities in balancing between teaching and research. Drawing from Chiang (2004), we assert that public universities in Uganda can enjoy more autonomy if they seek other sources of funding and depend less on government funding.

Institutional autonomy grants an organization the ability to quickly and successfully source and exploit resources faster than its competitors. Resource dependency theory recognizes the fact that institutions exist in an environment with other organizations with which they must not only interact but also compete for resources (Pfeffer \& Salancik, 1978). In the wake of increased demand for higher education and the dwindling government funding, Davis and Cobb (2010) assert that resource dependency theory underscores the importance of organizations devising strategies of survival and to enhance their own autonomy, while also maintaining stability in the organization's exchange relation with the external environment. However, in a bid to source resources from outside the institutions, autonomy and academic freedom are compromised (Lebeau \& Papatsiba, 2016). This is evident in collaborative research and cases where research agendas are set by international agencies like the World Bank.

In the current knowledge economy, universities are tasked to become more relevant and contribute directly to socio-economic development. This necessitates a move away from Mode 1 to Mode 2 forms of knowledge with serious funding implications (Gibbons, Limogens, Nowotny, Trow, Scott, \& Schwartzman, 1994). Governments are slowly granting autonomy to public institutions because they cannot meet the financial demands of the institutions and therefore allow them seek other sources of funding (Gul,et al., 2010). Universities are turning entrepreneurial and engaging in academic capitalism in order to fill funding gaps (Santiago et al, 2006). These two notions require the university to devise strategies for competing for resources in order to survive placing new demands on academics and tilting the balance towards research. Consequently, the phrase 'publish or perish' is common among faculty in public universities in Uganda. 
The managerial oversight that comes with universities turning entrepreneurial and to academic capitalism calls for greater accountability from academics and higher productivity (Capano, 2008; Gehrke \& Kezar, 2015; Santiago et al., 2006). This market driven orientation puts emphasis on research and makes the research environment more competitive. Academics are all out searching for research project grants in order to publish, thus giving little time to teaching. Such practices exhibit how institutional autonomy can be used to suffocate academic freedom. In agreement with Appiagyei-Atua et al. (2015) we assert that academic freedom is the instrument through which knowledge production, teaching and research quality, consequently the excellence of universities are realized. Thus, institutional autonomy should enhance academic freedom rather than suffocate it.

It has been observed in the findings that public universities in Uganda are semi-autonomous and are allowed to take a lot of decisions without government interference. This is so because governments are trying to move away from direct control on the institutions but expect accountability (Capano, 2008; Taiwo, 2012). Therefore, it is not complete autonomy since the accountability policy still gives government influence over the institutions for instance, if government releases a certain amount of money for research, the university is not expected to divert it to any other more pressing need. Such strict accountability policies affect the balance between teaching and research.

The important role of the university in the knowledge society places it in a paradoxical position. This has caused governments to take keen interest in influencing what takes place in these institutions, but at the same time enabled institutions to enjoy a great deal of autonomy. Through policy formulations, governments are setting priorities in knowledge fields that are considered potential contributors to economic growth and national development (Olsen, 2007). As exemplified by the Uganda National Science, Technology and Innovation Policy (2008), emphasis is on building excellence in research, technology and innovation. The question is where does teaching fit in such a policy environment? On the other hand, reduction in government funding has made institutions to look out for other funding agencies giving them the opportunity to strengthen their grip on the production and management of knowledge. As more actors enter in the field of governing knowledge, state influence reduces as well.

Consequently, the entry of external forces into university affairs has changed the environment in which academics carry out their work and has great implications for balancing between research and teaching. Academics are expected to adjust and adapt to the changing dynamics of their work. Their professional autonomy (academy freedom) is threatened by competing demands of research and teaching as external research agencies and public policies put pressure on them to engage more in research than teaching.

\section{Conclusion and Recommendations}

The $21^{\text {st }}$ century university must stay abreast with the pace and depth of change in the knowledge economy which has profound effects on the university regardless of the established traditions of teaching and research, structures and the individual threats and challenges which they are facing (Olsen, 2007). If universities insist on retaining concepts of autonomy and academic freedom which do not permit an accommodation with external forces, they will find themselves marginalized as public and private bodies opt to have their research done elsewhere; and as students choose other types of institutions in which to obtain the education they desire. On the other hand, if the universities submit to every demand made upon them by giving into every political caprice and student demands, they will surrender their very distinctive characteristic of commitment to open and independent inquiry.

Basing on the resource dependency theory, we conclude that pseudo-autonomy constrains faculty independence in research and teaching as external funding conditionality tilts the balance towards research. Control over resources enhances autonomy and academic freedom therefore public universities in Uganda need autonomy and academic freedom in order to harness resources from their environment for pursuing the functions of teaching and research. Unless they have autonomy, they cannot devise strategies to access resources sustainably. If universities are to be autonomous and utilize the resources acquired effectively without interference, the balance between research and teaching is likely to be achieved.

We therefore recommend that public universities in Uganda ought to revisit the professional work of the academics in the wake of increasing demands in order to balance between research and teaching. Otherwise the teaching dimension of their work will be stifled to the detriment of the learners. Internal policies should not be biased to one function of the university only. In order to balance between the functions of teaching and research, institutional autonomy should be used to promote academic freedom and not to suffocate it. Universities need to take responsibility to nurture autonomy and academic freedom within their own communities on the one hand, and on the other hand, governments and the public must respect the rights of universities to serve as centers of completely free inquiry and of social criticism. Research and teaching must be conducted according to plans established by the public universities in the exercise of their autonomy in the right of their resources. 


\section{References}

Abrutyn, S. (2009). Toward a general theory of institutional autonomy. Sociological Theory, 27(4). Retrieved from stx.sagepub.com

Akalu, G. A. (2014). Higher education in Ethiopia: Expansion, quality assurance and institutional autonomy. Higher Education Quartely, 68(4). 394-415. http://dx.doi.org/10.1111/hequ.12036

Appiogyei-Atua, K., Beiter, K., \& Karran, T. (2015). The capture of institutional autonomy by the political elite and its impact on academic freedom in African universities. Higher Education Review, 47(3).

Armbruster, C. (2008). Research universities: Autonomy and self-reliance after the entrepreneurial university. Policy Futures in Education, 6(4). Retrieved from www.wwwords.co.uk/PFIE

Asiimwe, S., \& Steyn, G. M. (2013). Obstacles hindering the effective governance of universities in Uganda. Journal of Social Sciences, 34(1), 17-27. Retrieved from www.krepublishers.com/--pdf--/jss-34-1-017-13-1423?

Brown, R. D., \& Krager, L. (2013). Ethical issues in graduate education: Faculty and student responsibilities. Journal of Higher Education, 56(4), 403-418.

Busitema University. (2011). Recruitment and Promotion Policy. Busitema University.

Busitema University Strategic Plan 2014/2015-2018/2019.

Capano, G. (2008). Looking for serendipity: The problematic reform of government within Italy's universities.

CEPES. (1992). Academic freedom and university autonomy. Proceedings of the international conference 5-7 may 1992, Sinai, Romania Bucharest. CEPES Papers on Higher Education. Retrieved from unesdoc.unesco.org/ulis/cgl-bin/ulis.pl?

Chiang, L. (2004). The relationship between university autonomy and funding in England and Taiwan. Higher Education, 48, 189-212. Retrieved from link.springer.com/article/10.1023/B.HIGH.0000034314.77435.bf.

Dill, D. D. (2001). The Regression of public research universities: Changes in academic competition and implications for university autonomy and accountability. Higher Education Policy, 14(1), 21-35. http:/dx.doi.org/10.1057/palgrave.hep.8390165

DiMaggio, P. J., \& Powell, W. W. (1991). Introduction. In W.W. P. a. P. J. DiMaggio (Eds.), The new institutionalism in organizational analysis (pp. 1-38). Chicago: The University of Chicago Press.

Emojong, J. A. (2015). Uganda lacks a research policy, varsity don says. Daily Monitor, Monday, November 9.

Fielden, J. (2008). Governance and Management for a world class institution. Retrieved from www.siteresources.worldbank.org/.../Fielden-Governance.ppt

Fumasoli, T., Gorritzka, A., \& Maassen, P. (2014). University autonomy and organizational change dynamics. ARENA Working Paper 8. Retrieved from www.arena.uio.no

Gehrke, S., \& Kezar, A. (2015). Unbundling the faculty role in higher education: Utilizing historical, theoretical and empirical frameworks to inform future research. Higher education handbook of theory and research, 30. http://dx.doi.org/10.1007/978-3-319-1835-1_3

Gibbons, M., Limogens, C., Nowotny, H., Trow, M., Scott, P., \& Schwartzman, S. (1994). The new production of knowledge. London: Sage.

Goverment of Uganda. National Council for Higher Education. (2008). Quality assurance framework for universities and the licensing procedure for higher education institutions: NCHE.

Group of 8 (Go8). (2008). In the interest of innovation: Time for a new approach to negotiating research agreements between the Commonwealth and Australian universities. A supplementary submission from the Group of Eight to the review of the National Innovation System.

Gul, H., Gul, S. S., Kaya, E., \& Alican, A. (2010). Main trends in the world of higher education, internalization and institutional autonomy. Procedia Social and Behavioural Sciences, 9, 1878-1884. http://dx.doi.org/10.1016/j.sbpro.2010.12.417

Henkel, M. (2007). Can academic survive in the knowledge society? Higher Education Research and Development, 26(1), 87-99. http://dx.doi.org/1080107294360601166836 
Ibrahim, O. (2010). Neo-liberalism and the subversion of academic freedom from within: Money, corporate cultures and 'captured' intellectuals in African public universities. Paper presented at the CODESRIA Conference on Academic Freedom and the Social Responsibility of the Intellectual in Africa, Oran, Algeria March 9th-11th 2010. Retrieved from www.codesria.org/1MG/pdf/ibrahim_oando_ogach.pdf

Kyambogo University Strategic Plan 2007/2008-2011/2012. Kyambogo University.

Kyambogo University. (2014). Human Resource Manual. Kyambogo University.

Lebeau, Y., \& Papatsiba, V. (2016). Conceptions and expectations of research collaboration in the European social sciences: Research, policies, institutional contexts and the autonomy of the scientific field. European Educational Research Journal, 1-18. http://dx.doi.org/10.1177/1474904116642777

Leisyte, L., \& Dee, R. J. (2012). Understanding academic work in a changing institutional environment: Faculty autonomy, productivity, and identity in Europe and the United States. Higher Education Handbook of Theory and Research, 27, 123-206.

Makerere University. (2006). Human Resource Manual. Makerere University, Kampala, Uganda

Makerere University. (2010). ICT Policy Master Plan (2010-2014). Makerere University, Kampala Uganda.

Makerere University. (2013). Annual Report. Kampala, Uganda.

Makerere University. (2013). Teaching and Learning Policy. Makerere University, Kampala, Uganda.

Makerere University. (2013). The Makerere University Student Evaluation of Teaching and Learning Policy. Makerere University, Kampala.

Makerere University. (2014). Makerere University Staff Promotions Policy. Makerere University, Kampala.

Makerere University. (2015). A call for applications. The New Vision, Monday 9, 2015.

Martin, M. (Ed) (2014). Governance reforms in higher education: A study of institutional autonomy in Asian countries. Paris: IIEP. Retrieved from unesdoc.unesco.org/images/oo22/022272/227242c.pdf.

Mbarara University of Science and Technology. (2010). Human Resource Manual. Mbarara University of Science and Technology.

McGregor, C. (2007). Report of the visitation committee to public universities in Uganda. Kampala, Uganda.

Ministry of Finance, Planning and Economic Development. (2008). Uganda National Science, Technology and Innovation Policy.

Muni University 5 Year Strategic Plan 2010/2011-2014/2015.

Nokkala, T., \& Bacevic, J. (2014). University Autonomy, Agenda setting and the construction of agency: The case of the European University Association in the European Higher Education Area. European Educational Resaerch Journal, 13(6). Retrieved from www.wwwords.ev/EERJ

Nybom, T. (2008). University autonomy: A matter of political rhetoric? Orebro University, SE 701 82, Orebro, Sweden.

Okai, O. N., \& Worlu, P. (2014). University autonomy and academic freedom: Implication for Nigerian Universities. International Journal of Scientific research in Education, 7(2), 191-201.

Olsen, J. P. (2007). The institutional dynamics of the European university. In Maassen, P. \& Olsen, J. P., University Dynamics and European integration, 25-54. Retrieved from dowmload.springer.com/stati/pdf/470/chp\%2531710

Osservatorio Univesitatum. (2005). Managing the university autonomy, 11(43), 39.

Owhondah, C. I. (2002). University autonomy and academic freedom. Unpublished Ph.D. thesis, Rivers State University of Science and Technology.

Pfeffer, J., \& Salancik, G. R. (1978). The external control of organizations: A resource dependence perspective. New York: Harper \& Row.

Pullin, D. (2004). Accountability, autonomy and academic freedom in educator preparation programs. Journal of Teacher Education, 55(4), 300-312. http://dx.doi.org/10.1177/0022487104266717

Purcell, W. (2008). Balancing the needs and expectations of society with the autonomy of higher education. Paris: OECD. 
Rostan, M. (2013). Teaching and research at Italian universities: Continuities and changes. The Changing AcademyThe Changing Academic Profession in International Comparative Perspective, 9, 89-112.

Santiago, R., Carvalho, T., Amaral, A., \& Meek, V. L. (2006). Changing patterns in the middle management of higher education institutions: The case of Portugal. Higher Education, 52, 215-250. http://dx.doi.org/10.1007/s10734-004-2747-3

Schmidt, K. E., \& Langberg, K. (2007). Academic autonomy in a rapid changing higher education framework. European Education, 39(4), 80-94. http://dx.doi.org/10.2753/EUE1056-4934390406

Sirat, M. (2010). Strategic planning directions of Malaysia's higher education: University autonomy in the midst of political uncertainties. Higher Education, 59(2), 461-473. http://dx.doi.org/10.1007/s10734-009-9259-0

Taiwo, A. E. (2012). The regulatory bodies, academic freedom and institutional autonomy Africa: Issues and challenges, Nigerian Example. Retrieved www.codesria.org/lMG/pdf/Taiwo_Adewal.pdf?314

The Republic of Uganda. (2001). Universities and Other Tertiary Institutions' Act 2001.

Yang, R., Vidovich, L., \& Currie, J. (2007). Dancing in a cage: Changing autonomy in Chinese higher education. Higher Education, 54, 575-592. http://dx.doi.org/10.1007/s10734-006-9009-5 